\title{
MEMOIRES ORIGINAUX \\ SUR LA LUTTE BIOLOGIQUE CONTRE LES INSECTES FORESTIERS AU MOYEN DES FOURMIS DU GROUPE \\ Formica rufa $\mathrm{L}$.
}

\author{
INTRODUCTION
}

BY

Mario Pavan

The Executive Bureau of the C.I.L.B. has entrusted me with the job of organizing the collaboration of experts in illustrating the various aspects of the problem of the biological control of damage making forest insects, by means of the Ants of the Formica rufa group. The subject, already known for many years, has had successful phases which have demonstrated its scientific importance and practical value. Up to now nobody has brought forward any serious objections to the practical use of this species in the struggle against insects pests to forest.

The known species of the Formica rufa group which are useful in biological control are Formica lugubris zETT., aquilonia YARR., rufa L., polyctena FoERst. which have ample European diffusion. Another species of the same group, Formica nigricans, not essentially forestal, has not the same significance because, in some cases, it has manifested damaging aspects to crops. In some countries (for example England and Italy) the range of various species are known. In other countries it will be the task of research in the next few years to bring deeper knowledge of such a fundamental aspect.

The data that are known about the systematic and biology of the Formica rufa group, make it likely that there will be new increases in knowledge in the next few years. The need for a deeper and wider systematic research, based on biology and assisted by the most modern methods of research, not exclusively morphological, is evident.

From the point of view of the importance of these ants for the defence of the woods, we have at our disposal very important references, especially thanks to the researche of many German Schools. An accurate census of the natural populations of the Italian Alps 
$\left(52000 \mathrm{~km}^{2}\right)$, carried out with the co-operation of 1500 agents of the State Forestal Corps, has made known the existence of more than a million nests of the four useful species, and it is calculated that these have a population of 300000000000 workers. These workers could destroy $14400000 \mathrm{~kg}$ of insects mostly damaging to forests, in an annual period of activity of two hundred days.

The field of beneficent activity of these ants in the defence of forests, however, has fairly strong limitations due to ecological requirements and to the characteristic behaviour of the various species and of their races. Their ecological characteristics tend towards the south of the range to colonize naturally high montainous zones. Their characteristic behaviour limits, their forestal usefulness to very important but well defined economic fields. In conclusion these ants should not be considered as a miraculous element but as a equilibrating factor in the relations between numerous species of insects and certain forest plants, above all, conifers.

Natural ecological limitations can be overcome, within certain limits (at least in the case of certain species) and to demonstrate this, the true results of climatization obtained in Germany in the natural range of single species (in particular Formica polyctena) can be mentioned, and also in Italy with the artificial extension of the natural Alpine diffusion of Formica lugubris for almost $600 \mathrm{~km}$ towards South.

It seems most important that the study of ants of the Formica rufa group continues in every section in a profitable general co-operation that will overcome not only the barriers of political confines of single nations, but also of continents.

I am grateful to the C.I.L.B. who by authoritative instigation encouraged us to collect data, shown by the series of contributions which we present. I thank my eminent colleagues Bruns, Lange, Gösswald, Kloft and Schmidt who have collaborated with us with the excellent works presented in this volume. In England, Holand, Belgium, France, Germany and Italy the problem is actively studied, and in numerous other countries it is attentively followed. The basis for an international co-operation exists and it is partly established. The next goal will be to achieve, also under the aupices of the C.I.L.B., a co-ordination of the common forces to obtain a minimum loss of effort, and better general success, and to realize within the range of common laws which are being created for the organization of the new Europe, a general law which protects the useful species of the ants of the Formica rufa group against every damage and destruction (1).

(1) In order to realize a profitable international co-operation, the C.I.L.B. has charged the writer to found an International Centre in Pavia for the study of the problem of the biological control by means of the ants of the Formica rufa group. 
In the name of Italy, whom I have the honour to represent at the C.I.L.B. as delegate of the Forestry Administration, I am happy to be able to communicate through " Entomophaga " that our country intends to open a list of those willing to take part in a wider collaboration in all sections with every other country and organization (1).

(Cattedra di Entomologia A graria dell'Università di Pavia, Italia.)

(1) As an act of collaboration, which also demonstrates the high estimation in which C.I.L.B. is held and the value attributed to its aims, the Italian Forest Administration offers to all adherents of C.I.L.B. and subscribers to "Entomophaga" a copy of a recent publication (M. Pavas, 1959. - Attività italiana per la lotta biologica con Formiche del gruppo Formica rufa contro gli insetti dannosi alle foreste. - Ministero Agricoltura $e$ Foreste, Collana Verde, $\}_{t}, 1-80$ ) which summarizes the last ten years of scientific and practical italian activity in the field of the biological control by means of the ants of the Formica rufa group. 